\title{
MODEL MULTILITERASI DALAM PERKULIAHAN PENDIDIKAN BAHASA DAN SASTRA INDONESIA
}

\author{
Esti Swatika Sari, Maman Suryaman, Beniati Lestyarini \\ Fakultas Bahasa dan Seni Universitas Negeri Yogyakarta \\ e-mail: esti_fbs@yahoo.co.id
}

\begin{abstract}
Abstrak
Penelitian ini bertujuan untuk mendeskripsikan model multiliterasi dalam perkuliahan Pendidikan Bahasa dan Sastra Indonesia. Metode penelitian yang digunakan adalah deskriptif kualitatif dengan melibatkan tiga mata kuliah, yakni Berbicara Dialektik, Membaca Kritis Kreatif dan Sintopis, dan Kajian Wacana. Data penelitian diperoleh dari hasil kuesioner dosen, wawancara dengan mahasiswa, dokumen tugas mahasiswa, materi pembelajaran dan sistem penilaian dosen. Hasil penelitian sebagai berikut. Pertama, pada mata kuliah Berbicara Dialektik, kompetensi multiliterasi yang dikembangkan adalah kompetensi linguistik, gestural, dan spasial. Kedua, pada mata kuliah Membaca Kritis Kreatif dan Sintopis, kompetensi linguistik, visual, audiovisual, dan spasial. Ketiga, kompetensi utama pada mata kuliah Kajian Wacana adalah kompetensi linguistik, spasial, dan visual. Multiliterasi dalam perkuliahan juga dapat dilihat dari situasi praktik, pembelajaran terbuka, refleksi pemikiran kritis, dan praktik transformatif.
\end{abstract}

Kata kunci: multiliterasi, kompetensilinguistik,pemikirankritis

\section{A MODEL OF MULTILITERACY IN THE INDONESIAN LANGUAGE AND LETERATURE EDUCATION COURSE}

\begin{abstract}
This study aims to describe a model of literacy in the Indonesian Language and Literacy Education course. It employed the qualitative descriptive method involving three subjects, namely Dialectical Speaking, Syntopical, Creative, and Critical Reading, and Discourse Analysis. The data were collected through a questionnaire for lecturers, interviews with students, student assignment documents, learning materials, and lecturers' evaluation system. The findings are as follows. First, in Dialectical Speaking, the multiliteracy competencies developed are linguistic, gestural, and spatial competencies. Second, in Syntopical, Creative, and Critical Reading, they are linguistics, visual, audiovisual, and spatial competencies. Third, in Discourse analysis, they are linguistics, spatial, and visual competencies. Multiliteracy in a course can also be viewed from the practice situation, open learning, critical thinking reflection, and transformative practice.
\end{abstract}

Keywords: multiliteracy, linguistic competency, critical thinking

\section{PENDAHULUAN}

Kesadaran terhadap keberagaman masyarakat sebagai dampak laju mobilisasi yang tidak lagi mengenal batas ruang dan waktu membawa konsekuensi logis bagi kelangsungan hidup manusia. Era digital dengan berbagai produk layanannya menjadi jalan yang efektif bagi perubahan cara berkomunikasi dengan seluruh masyarakat di seluruh penjuru dunia (Borsheim, Merrit, dan Reed, 2008; Williams, 2008; Graham, Benson, Fink, 2010). Hal ini secara praktis dapat diamati dari banyaknya penggunaan akses internet untuk memperoleh pengetahuan sekaligus berbagi pengetahuan baik melalui buku elektronik (eBook), jurnal elektronik, blog, wiki, Facebook, dan fasilitas-fasilitas lainnya. 
Perubahan cara berkomunikasi tersebut tidak dapat dilepaskan dari konsep literasi (baca-tulis) di era global. Pandangan tradisional mengisyaratkan bahwa teks merupakan simbol/tulisan yang tercetak (printed text). Sementara itu, dengan berbagai fasilitas yang ada sekarang, teks bukan hanya tulisan yang tercetak namun tulisan yang ada di internet, gambar, film, video dapat dipandang sebagai teks yang tentu saja dalam kegiatan interpretasinya, konteks harus senantiasa diperhatikan. Hal ini menjadi dasar bagi munculnya konsep multimodal dalam dunia pendidikan (multimodal education) yang dirintis oleh New London Group (1996) dan diikuti oleh berbagai peneliti atau organisasi dengan asumsi pada banyaknya bahan (modal) yang dapat digunakan untuk menyelenggarakan proses pembelajaran (Hassett dan Curwood, 2009; Borsheim, Merrit, dan Reed, 2008; Williams, 2008; Graham, Benson, Fink, 2010).

Konsep multimodal dalam pendidikan yang mengacu pada banyaknya jenis bahan yang dapat digunakan dalam pembelajaran literasi berimplikasi pada muculnya konsep multiliterasi. Konsep ini merupakan wujud kesadaran terhadap beragamnya cara manusia untuk berkomunikasi dan melakukan aktivitas baca dan tulis maupun jenis bahan atau media untuk kegiatan baca dan tulis. Hal itu berimplikasi pada luasnya analisis kritis yang harus dilakukan untuk menginterpretasi teks.

Praktik pembelajaran bahasa Indonesia yang meliputi keterampilan bahasa dan sastra Indonesia hendaknya relevan dengan konteks masyarakat. Kesadaran terhadap multiliterasi semestinya terintegrasi dalam proses pembelajaran. Guru atau dosen maupun siswa atau mahasiswa dapat memanfaatkan berbagai media pembelajaran yang relevan dengan konteks kehidupan mereka, sekaligus mengembangkan pemikiran kritis agar pemanfaatan tersebut dapat memberikan nilai guna baik bagi pribadi siswa atau mahasiswa maupun guru atau dosen.

Penelitian ini melibatkan mahasiswa semester 2 yang menempuh mata kuliah Berbicara Dialektik, semester 4 yang menempuh mata kuliah Membaca Kritis, Kreatif, dan Sintopis, serta semester 6 yang menempuh mata kuliah Kajian Wacana. Masing-masing mata kuliah dipilih satu kelas yang representatif dengan jumlah \pm 20 mahasiswa pada tiap kelas. Pemilihan mata kuliah ini didasarkan pada pentingnya aspek literasi (baca-tulis) yang harus dikembangkan dalam mata kuliah tersebut serta pemanfaatan komponenkomponen multiliterasi sehingga dapat digunakan dengan lebih maksimal.

Bagaimana aspek-aspek multiliterasi pada perkuliahan pendidikan bahasa dan sastra Indonesia yang tercermin dalam kompetensi multiliterasi khususnya pada mata kuliah Berbicara Dialektik, Membaca Kritis Kreatif dan Sintopis, serta Kajian Wacana? Bagaimana respons mahasiswa dan dosen terhadap aspek kompetensi multiliterasi dalam perkuliahan? Penelitian ini berusaha untuk menjawab pertanyaan-pertanyaan tersebut.

Pengetahuan terhadap adanya keberagaman yang hidup dalam masyarakat global semestinya diikuti dengan kesadaran untuk memahaminya. Keberagaman dalam hal ini tidak hanya dipahami sebagai banyaknya ras, etnik, namun juga cara pandang, cara hidup, perubahanperubahan dalam masyarakat, bahkan perkembangan teknologi di era digital yang berimplikasi sangat besar pada cara manusia dalam berkomunikasi. Pemahaman kritis terhadap semua elemen tersebut sekaligus pengenalan diri sebagai pribadi di tengah masyarakat global diharapkan dapat membawa pemahaman multikultural yang lebih baik untuk kesejahteraan manusia.

Perkembangan paradigma bahasa dapat dikaji lebih dalam dari pernyataan beberapa ahli, mulai dari zaman Saussuri- 
an yang bersifat struktural sampai dekonstruksi yang memiliki perspektif berbeda. Vygotsky (1986) menekankan pentingnya penggunaan bahasa dikaitkan dengan aspek sosial sebagai pondasi dasar bagi pembelajaran bahasa itu sendiri. Melalui konsep zona perkembangan proksimal, hal ini akan membantu guru memahami proses pembelajaran bahasa melalui eksplorasi potensi siswa dan memberikan fasilitas sehingga siswa dapat bekerja secara mandiri. Selain itu, pendidik juga dapat mendesain pembelajaran yang strategis dan visibel serta kolaborasi bermakna dengan siswa dalam upaya mendapatkan hasil yang terbaik bagi siswa. Sementara itu, teori-teori kontemporer yang berkembang sekitar dua dekade terakhir seperti yang dikemukakan oleh Edelsky (2006), Fairclaugh (1989; 1992), Gee (1992), Kress (2003) semakin menambah khasanah paradigma pembelajaran bahasa di era global.

Pembelajaran bahasa sudah semestinya mengelaborasi pemahaman terhadap studi bahasa dengan segala kompleksitas kajian sosial, budaya, ekonomi, politik, serta perkembangan pola pikir dan cara hidup masyarakat global. Keberagaman menuntut adanya fleksibilitas, pergerakan yang dinamis, dan kajian yang lebih mendalam dan komprehensif. Namun, fleksibilitas ini harus diimbangi dengan penguatan dan kesaradan diri serta kajian kritis terhadap segala fenomena yang ada khususnya dalam pembelajaran bahasa karena jika tidak ada balancy maka pribadi akan tergerus oleh perkembangan jaman.

Pemahaman terhadap prinsip multimodal menjadi dasar bagi perkembangan model pembelajaran literasi pada sepuluh tahun terakhir. Seperti yang diungkapkan oleh Vasquez (2003) bahwa multimodal adalah konsep "meaning and knowledge are built up through various modalities including images, texts, symbols, and interactions". Dengan kata lain, teks dipahami sebagai semua jenis cara berkomunikasi.
Hasset dan Curwood (2009) dalam jurnal mengenai multimodal education mengutip pendapat Coiro, Knobel, Lankshear, dan Leu sebagai berikut.

In today's primary classroom, the definition of "text" has expanded to include multiple modes of representation, with combined elements of print visual images, and design. Emergent research on literacy highlights the imaginative, interpretive, nonlinear, interactive, dynamic, visual, and mobile feature of communication.

Dalam jurnal yang berjudul Rereading the Sign: Multimodal Transformation in the field of literacy education, Siegel (2006) menguatkan konsep multimodal dalam pembelajaran bahasa bahwa language arts education can no longer ignore the way that our social, cultural, and economic world now require facility with texts and practice involving the full range of representational modes. Bahkan, karena adanya keberagaman budaya, bahasa Inggris pun terpecah menjadi berbagai jenis dan berkembang menjadi bahasa Inggris yang berbedabeda, baik karena dipengaruhi oleh aksen maupun perubahan bentuk kata (Barron, 2007). Sementara itu, Bazemer dan Kress (2008) menyatakan pentingnya mode sebagai bentuk sumber sosial dan kultural untuk melakukan pemaknaan.

Pemahaman mengenai konsep multimodal inilah yang menjadikan konsep multiliterasi dikenalkan oleh New London Group (1996) dalam Pedagogy of Multiliteracy: Designing Social Feature. Manusia tidak hanya membaca atau menulis, namun mereka membaca dan menulis dengan genre tertentu yang melibatkan tujuan sosial, kultural, dan politik (Caughlan, 2008). Dalam upaya peningkatkan kompetensi multiliterasi, penggunaan grafik, gambar, setting tulisan, foto, presentasi, gestur, bermain drama, baik dalam bentuk cetak maupun elektronik menjadi sumber dan media pembelajaran yang menarik. Meskipun penggunaan media pembela- 
jaran seperti ini sudah sering dilakukan, namun pemanfaatan dan pemikiran kritis terhadap unsur-unsur yang ada dalam setiap komponen media dan model pembelajaran tersebut belum dilakukan secara maksimal. Sebagai contoh saja, media Facebook kebanyakan dimanfaatkan mahasiswa untuk meng-update status saja, namun belum banyak dimanfaatkan untuk kegiatan pembelajaran. Padahal, hampir semua mahasiswa setiap hari selalu membuka account Facebook mereka.

Laporan PISA menekankan bahwa indikator kunci untuk kompetensi membaca adalah keberagaman jenis kemampuan membaca. Artinya, konsep multliterasi menjadi bagian penting dari penilaian kompetensi membaca internasional. Pengenalan terhadap berbagai bentuk genre berbahasa dan berkomunikasi yang sekarang ini juga dikenal sebagai pendekatan genre (Knapp dan Watkins, 2005) tidak terlepas dari konsep multiliterasi karena dalam pendekatan ini. Teks memiliki genre tertentu yang kemudian dilihat relevansi dan praktiknya pada konteks nyata, seperti teks dalam media cetak maupun elektronik.

Ada empat gambaran dimensi pembelajaran multiliterasi yang dikenalkan oleh New London Group (1996). Pertama, situated practice, yang menggambarkan pengalaman hidup peserta didik. Kedua, overt instruction, yang melibatkan metabahasa untuk mendekonstruksi konsep dan cara multimodal dimana makna dikonstruksi. Ketiga, critical framing of the cultural and social context, dimana makna dikenalkan dan dipahami sebagai konteks kultural dan sosial. Keempat, transformed practice, sebagai upaya untuk mentransformasikan makna dalam dimensi sosial dan kultural.

Dalam proses pembelajaran, aktivitas membaca maupun menulis tidak berdiri sendiri, namun dipengaruhi oleh konteks, budaya, dan praktik sosial. Penting sekali untuk disadari bahwa kekayaan pengala- man mahasiswa dapat memunculkan identitas situasi sosial yang beragam (Williams, 2008). Pada praktinya, dosen harus mengarahkan mahasiswa untuk terlibat dalam variasi teknologi, literasi, dan pedagogi (Borsheim, Merrit, dan Reed, 2008). Mencari, mengumpulkan, mengelola, dan mengevaluasi sumber-sumber secara online, menyusun teks untuk berbagai keperluan, tujuan, dan audiens, serta membangun kesadaran kritis tentang bagaimana membuat dan menggunakan teks di era teknologi globalisasi dapat menjadi panduan dalam mengelola kelas. Mahasiswa di sisi lain juga semestinya terlibat secara aktif, mandiri dalam belajar, dan memanfaatkan berbagai jenis teks yang beragam dalam konsep multiliterasi sebagai referensi pengetahuan sekaligus wujud praktik kerja dalam melaksanakan tugas perkuliahan.

Praktik multiliterasi yang dilakukan oleh Graham, Benson, dan Fink (2010), didasarkan pada aspek multimodal literasi yang meliputi kompetensi linguistik, kompetensi visual, kompetensi audio, kompetensi gestural, dan kompetensi spasial dimana siswa diarahkan untuk memanfaatkan media film dan acara pertunjukkan di televisi sebagai bahan analisis. Kompetensi linguistik menitikberatkan pada analisis terhadap bahasa lisan sebagaimana dalam kehidupan sehari-hari baik struktur, organisasi, gaya bahasa, kepribadian tokoh, dan konteks kultural masyarakat dalam kehidupan tokoh. Kompetensi spasial berkenaan dengan analisis terhadap penggunaan ruang dan pengaruhnya pada karakter tokoh. Kompetensi gestural menitikberatkan pada analisis terhadap aksi yang diperankan oleh tokoh. Kompetensi visual berkenaan dengan bagaimana sesuatu dapat diamati baik hal, sikap atau barang.

Dengan mengadopsi praktik multiliterasi yang dilakukan Graham, Benson, dan Fink (2010) di atas, kajian terhadap model multiliterasi dalam perkuliahan 
bahasa dan sastra Indonesia ini dilakukan. Secara garis besar, kompetensi linguistik mahasiswa berkaitan dengan pemikiran kritis terhadap unsur-unsur kebahasaan dan hubungannya dengan konteks masyarakat global. Kompetensi spasial berkaitan dengan kesadaran spasial yang dapat dimanfaatkan untuk lebih memahami sumber materi dan berkarya secara inovatif untuk memnafaatkan unsur-unsur spasial yang ada. Kompetensi visual melihat bagaimana respons kritis mahasiswa dalam mencermati fenomenafenomena yang terjadi di sekitar yang dapat dimanfaatkan untuk sumber dan media perkuliahan bahasa dan sastra Indonesia. Kompetensi audio berkenaan dengan kepekaan auditif mahasiswa untuk mencermati bahasa yang dilisankan maupun respon audio yang dituliskan, misalnya dalam novel ada keterangan suara-suara untuk membangun suasana. Kompensi gestural berkaitan dengan analisis kritis sekaligus praktik perkuliahan yang mengedepankan gestur, misalnya saja pementasan puisi, pembacaan pidato, presentasi, dan sebagainya.

\section{METODE}

Penelitian dilaksanakan di Universitas Negeri Yogyakarta Fakultas Bahasa dan Seni dan dilaksanakan selama tujuh bulan yakni dari Desember 2010 sampai Juni 2011. Adapun subjek dalam penelitian ini meliputi mahasiswa PBSI FBS UNY semester 2 yang menempuh mata kuliah Berbicara Dialektik, semester 4 yang menempuh mata kuliah Membaca Kritis, Kreatif, dan Sintopis, serta semester 6 yang menempuh mata kuliah Kajian Wacana dimana dari masing-masing mata kuliah dipilih satu kelas yang representatif dengan jumlah \pm 20 mahasiswa pada tiap kelas.

Penelitian ini merupakan penelitian kualitatif yang menggunakan pendekatan deskriptif interpretatif. Data dalam penelitian ini dikumpulkan melalui ob- servasi yang dilengkapi dengan pedoman observasi, wawancara dengan berdasar pada pedoman wawancara, dokumen untuk melihat respon mahasiswa, serta dokumentasi melalui foto dan video. Semua data kemudian dianalisis kemudian saling di-crosscheck-an. Validitas dan reliabilitas penelitian dicapai melalui cek anggota (member check) dan cek orang luar (outsider check). Diskusi dan konsultasi dengan pakar bidang pendidikan bahasa, pakar pembelajaran bahasa, dan juga pakar sastra dilakukan untuk memperoleh keakuratan data.

\section{HASIL DAN PEMBAHASAN Multiliterasi dalam Perkuliahan Berbi- cara Dialektik}

Kompetensi multiliterasi yang tampak dari silabus cenderung pada kompetensi gestural yakni dengan mempraktikkan berbagai jenis cara berkomunikasi kelompok misalnya bertegur sapa, melakukan diskusi, rapat, seminar, melakukan negosiasi, konferensi, dan wawancara. Semua jenis komunikasi ini dipraktikkan dalam perkuliahan karena menjadi standar mata kuliah. Hal ini tentu saja sangat sesuai dengan konsep pembelajaran multiliterasi di mana modal-modal yang dipakai dalam pembelajaran bahasa sangat beragam baik jenis maupun bentuknya.

Kompetensi multiliterasi lain yang tampak yakni kompetensi spasial. Kompetensi ini muncul pada berbagai teknik berkomunikasi kelompok yang menuntut mahasiswa untuk menjadi penampil yang baik, misalnya dalam praktik seminar, konferensi, kolokium, dan lain-lain. Mahasiswa harus mampu memposisikan diri di depan audiens serta menguasai ruang sekaligus suasana.

Namun, dalam standarisasi kompetensi mata kuliah pada silabus belum tampak jelas jenis kompetensi yang menjadi standar kompetensi mahasiswa. Hal ini dapat dilihat dari kata kerja operasional yang dipakai yang hampir semuanya "mema- 
hami" konsep dasar atau hakikat. Padahal, untuk menjadi terampil berbicara khususnya berkomunikasi kelompok, mahasiswa harus mempraktikkan berbagai jenis komunikasi kelompok tersebut. Hanya ada satu standar yang menggunakan kata kerja operasional "melakukan" yakni pada standar 7 "melakukan seminar".

Kegiatan perkuliahan yang dilakukan menunjukkan bahwa aspek multiliterasi sudah dilakukan dengan baik. Berbagai metode teknik berkomunikasi dikenalkan sekaligus dilatihkan pada mahasiswa. Teknik-teknik tersebut sangat bermanfaat bagi mahasiswa baik selama kuliah maupun ketika sudah memasuki dunia kerja. Tegur sapa, koversasi, diskusi, rapat, diskusi panel, debat, konferensi, wawancara, negosiasi, dan kolokium merupakan sejumlah teknik berkomunikasi kelompok yang diajarkan. Hal ini mengindikasikan bahwa konsep multimodal sudah dilaksanakan dengan baik pada mata kuliah Berbicara Dialektik.

Perkuliahan Berbicara Dialektik memanfaatkan beberap jenis tagihan, yakni makalah, tugas kelompok, dan pada akhir semester ada tagihan proyek bagi mahasiswa yaitu mengadakan seminar dari makalah yang sudah dibuat. Hal ini sangat sesuai dan mendukung pengembangan pembelajaran multiliterasi. Mahasiswa diberi ruang kebebasan untuk memaksimalkan potensi yang dimiliki melalui berbagai jenis tugas. Dalam seminar, tentunya kompetensi gestural, kompetensi lingusitik, kompetensi spasial banyak dimanfaatkan.

\section{Multiliterasi dalam Perkuliahan Mem- baca Kritis, Kreatif, dan Sintopis}

Berbagai jenis teks dimanfaatkan sebagai sumber atau bahan perkuliahan Membaca Kritis Kreatif dan Sintopis. Hal ini sesuai dengan konsep multiliterasi bahwa berbagai modal dapat digunakan dalam pembelajaran. Genre teks sangat penting untuk dijadikan bahan analisis, apalagi dengan semakin berkembangnya pengetahuan dan teknologi, teks yang dulu hanya dimaknai sebagai teks tercetak (printed text) sekarang sudah bertambah jenisnya. Misalnya saja, teks dalam bentuk elektronik seperti koran online, e-book, artikel dari internet, teks dalam film atau video, dan sebagainya.

Kompetensi-kompetensi yang tampak jelas dikembangkan dilihat dari deskripsi mata kuliah tersebut yakni kompetensi visual, kompetensi spasial, dan kompetensi gestural. Kompetensi visual terlihat dari beragam teks tertulis yang dimanfaatkan mahasiswa dengan menggunakan kemampuan visualnya. Kompetensi gestural tampak dari membuat produk-produk kreativitas sebagai efek dari kegiatan membaca yang kemudian dipresentasikan sebagai tugas. Kompetensi spasial dimana mahasiswa dapat memanfaatkan saranasarana di sekitar yakni berbagai jenis teks yang relevan dengan kehidupan sekarang dan bagaimana cara memanfaatkan beragam teks tersebut.

Dari deskripsi standarisasi kurikulum terlihat bahwa mata kuliah ini menuntut mahasiswa untuk terlibat aktif dengan memanfaatkan berbagai genre teks yang ada. Teks fiksi, nonfiksi/ragam teks ilmiah dijadikan media dalam perkuliahan. Metode perkuliahan dilakukan mulai dari pembelajaran tatap muka, penugasan, praktik/latihan, dan diskusi. Praktik dilakukan baik secara kelompok maupun individu. Bahkan, ada juga kunjungan lapangan yakni kunjungan ke perpustakaan yang dapat dijangkau oleh mahasiswa untuk membuat kajian kritis bagaimana pemanfaatan perpustakaan yang dikunjungi.

Pada setiap keterampilan membaca, mahasiswa wajib membuat serta mempresentasikan karya yang dibuat. Untuk membaca kritis, keterampilan yang diajarkan yakni membuat kritik terhadap artikel ilmiah. Artikel ilmiah khususnya yang berbentuk jurnal ilmiah sangat penting 
untuk dikuasai mahasiswa dan menjadi sumber referensi kuat kedua sesudah buku. Mahasiswa lalu membuat kajian kritis terhadap sumber yang dibaca sesuai dengan teori dan prosedur membaca kritis.

Dalam kegiatan tersebut, tampak kompetensi linguistik yakni pemahaman terhadap teks bacaan diutamakan. Kompetensi visual tentu saja juga dimanfaatkan karena membaca berkaitan dengan pemanfaatan media visual seperti teks. Kompetensi gestural juga banyak dikembangkan melalui presentasi dan diskusi kelas. Pada keterampilan membaca kritis dan kreatif, presentasi dilakukan agar hasil kajian membaca kritis dan produk kreativitas dapat dinilai oleh mahasiswa lain. Mahasiswa mempresentasikan produk kreatif teknologi berupa program untuk alternatif media pembelajaran yang dapat diterapkan di sekolah atau perguruan tinggi. Dalam hal ini, kompetensi audiovisuallebih tampak jelas karena media menggunakan perangkat audiovisual. Dari kegiatan tersebut, dapat dilihat cermin pembelajaran multiliterasi diterapkan dalam mata kuliah membaca.

Tagihan dalam membaca kritis yakni praktik analisis kritis bacaan berupa artikel ilmiah. Tagihan untuk kegiatan ini berupa tagihan individu sehingga masingmasing mahasiswa harus membuat kajian kritis. Hal yang menarik yakni tugas mahasiswa dibuat menjadi kumpulan laporan kajian kritis artikel ilmiah yang dibukukan.

\section{Multiliterasi dalam Perkuliahan Kajian Wacana}

Deskripsi mata kuliah ini memperlihatkan kecenderungan pada pengembangan kompetensi visual dan spasial. Kompetensi visual terkait dengan wacana-wacana yang dikaji sedangkan kompetensi spasial terkait pemahaman mahasiswa mengenai pemahaman dan pemanfaatan potensi-potensi berbagai jenis wacana yang dapat digunakan sebagai sumber atau bahan ajar.

Satu kelemahan dalam kurikulum Kajian Wacana menurut wawancara dengan dosen yakni silabus yang digunakan untuk prodi PBSI dan BSI sama, padahal penekanan pada kedua prodi tersebut berbeda. Oleh karena itu, Dosen secara independen melakukan improvisasi untuk kedua prodi. Perkuliahan Kajian Wacana pada prodi PBSI lebih mendayagunakan wacana-wacana yang berhubungan dengan pendidikan dan pembelajaran. Sementara itu, pada prodi BSI, perkuliahan lebih ditekankan pada mendayagunakan wacana-wacana murni dengan kajian yang lebih mendalam.

Mata kuliah Kajian Wacana banyak memanfaatkan media kultural sosial sebagai bahan kajian. Sebagai contoh, banyak wacana iklan yang digunakan sebagi bahan kajian bagi mahasiswa. Ada pula wacana-wacana yang berkembang di masyarakat misalnya wacana plang, spanduk, dan sebagainya. Media yang dimanfaatkan dalam perkuliahan Kajian Wacana tampak pada Gambar 1.

Dari berbagai jenis media kajian wacana di atas, tampak bahwa mahasiswa cukup kreatif memanfaatkan kemampuan spasial mereka. Artinya, potensi-potensi sosial kultural yang ada di sekitar khususnya dalam konteks kehidupan mahasiswa dimanfaatkan sebagai media perkuliahan. Hal ini sesuai dengan konsep pembelajaran bahasa bahwa laboratorium bahasa adalah dunia sekitar, manusia beserta konteks yang ada di sekitarnya. Kajian wacana dalam hal ini sebagai jalan bagi mahasiswa untuk lebih memahami segala fenomena yang ada di sekitar. Dengan memahami fenomena-fenomena di sekitar, pemahaman terhadap diri pribadi mahasiswa diharapkan semakin baik sehingga mahasiswa lebih mampu memberikan peran bagi kehidupan. 


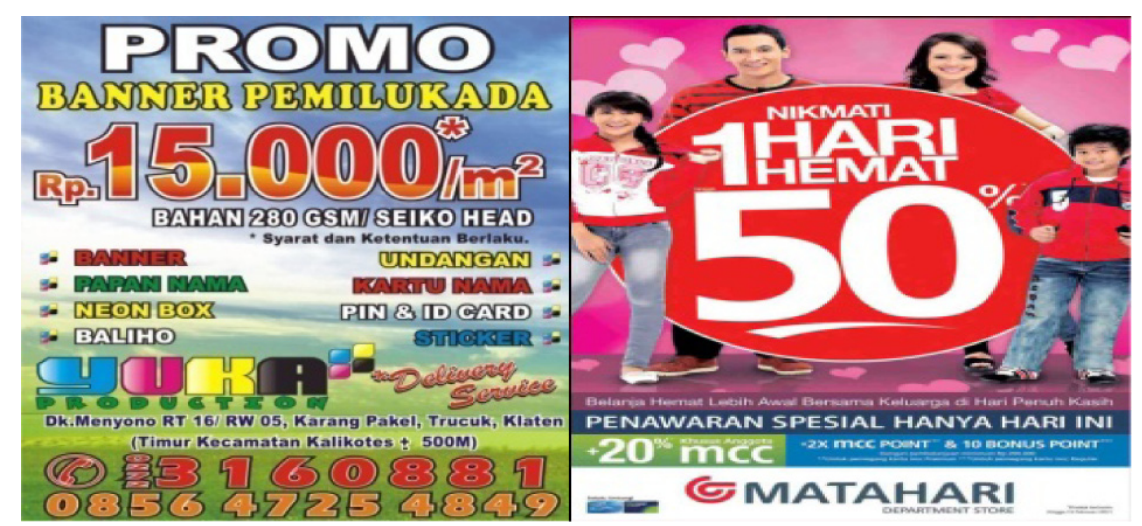

Gambar 1. Berbagai Jenis Teks yang Dimanfaatkan dalam Kajian Wacana

\section{Situasi Praktik Kompetensi Multiliterasi dalam Perkuliahan}

Situasi praktik dalam konsep pembelajaran multiliterasi merupakan wujud praktik yang bermakna dari komunitas belajar. Dengan praktik pembelajaran yang mendorong terciptanya situasi ini, diharapkan para peserta didik lebih menyadari peran dan fungsinya masing-masing dalam konteks kehidupan sehingga lebih mampu memberikan manfaat bagi masyarakat.

Dalam perkuliahan Berbicara Dialektik mahasiswa dilatih untuk mampu memberikan peran dalam komunikasi di masyarakat, misalnya untuk berkolaborasi dalam satu acara dan berbagi peran untuk menjadi moderator seminar, MC dan sebagainya. Dalam perkuliahan Membaca Kritis Kreatif dan Sintopis, mahasiswa diberikan kesempatan untuk berpikiran kritis dan juga berkreativitas. Bahkan ada beberapa produk mahasiswa yang potensial untuk dijadikan komoditas. Misalnya saja berbagai produk makanan, seni, teknologi, budaya, sastra, dan sebagainya.

Dalam perkuliahan Kajian Wacana, situasi praktik tercermin dari praktik analisis terhadap wacana-wacana yang erat dengan kehidupan sosial. Dengan memahami fenomena-fenomena wacana maka pemahaman etrhadap sosial budaya, perubahan politik, transformasi publik, dan penghormatan terhadap hak pribadi akan lebih tercipta dengan baik. Hal ini menjadi tujuan dari pendidikan yakni untuk membentuk peserta didik yang berkarakter mulia, cerdas, dan berguna.

\section{Pembelajaran Terbuka Kompetensi Mul- tiliterasi dalam Perkuliahan}

Pembelajaran terbuka dalam konteks pendidikan multiliterasi menekankan pada pembelajar sebagai subjek pembelajaran. Dalam konteks ini, mahasiswa diberi kesempatan seluas-luasnya untuk aktif dan progresif dalam merespons segala fenomena yang ada. Bila diperlukan, perkuliahan dilaksanakan secara bertim agar ada kolaborasi yang baik antardosen sehingga tercipta iklim akademik dan diskusi yang berguna untuk pengembangan keilmuan.

Dalam ketiga situasi perkuliahan, baik Berbicara Dialektik, Membaca Kritis, Kreatif, dan Sintopis, serta Kajian Wacana tampak bahwa pemberian kesempatan kepada mahasiswa sudah dilakukan. Mahasiswa dapat mengeksplorasi kemampuan dan pengetahuan yang dimiliki untuk kepentingan perkuliahan.

\section{Refleksi Pemikiran Kritis Kompetensi Multiliterasi \\ Refleksi pemikiran kritis tercermin dalam metode perkuliahan yang dilak-}


sanakan. Dosen tidak hanya asal ceramah dan memberikan konsep-konsep tanpa ada pemikiran kritis. Pengenalan konsep dengan cara berpikir filosofis sangat penting untuk membangun pemikiran kritis mahasiswa. Pemilihan dan pemanfaatan sarana-sarana multiliterasi sendiri sebenarnya bertolak dari pemikiran kritis terhadap potensi dari sarana-sarana tersebut.

Perkuliahan Berbicara Dialektik misalnya, mendorong mahasiswa untuk berpikir kritis bagaimana mencari topiktopik yang menarik sebagai bahan seminar. Dalam perkuliahan Membaca Kritis Kreatif Sintopis, ada jenis membaca kritis. Mahasiswa diarahkan untuk kritis dalam menanggapi ide-ide yang dikemukakan oleh penulis. Hal itu tercermin dalam tugas-tugas mahasiswa yang dapat dilihat pada lampiran. Sementara itu, mata kuliah Kajian Wacana memberikan kesempatan pada mahasiswa untuk mengkaji secara kritis wacana-wacana yang beredar di masyarakat yang erat dengan kehidupan mahasiswa dan sebagai bagian dari masyarakat.

\section{Praktik Transformatif}

Praktik transformatif berkaitan dengan kemampuan menciptakan kembali konsep dari hasil belajar dan menyesuaikan dengan tujuan yang akan dicapai. Mahasiswa belajar mengenai konsep pada masing-masing mata kuliah, namun dari konsep tersebut mahasiswa menciptakan kembali pemahaman baru yang disesuaikan dengan tujuan belajarnya.

Misalnya saja dalam mata kuliah Membaca Kritis Kreatif dan Sintopis, mahasiswa memahami bahan bacaan kemudian dari bacaan tersebut tercipta pemahamn baru yang diimplementasikan dalam menciptakan produk atau perubahan tingkah laku.

Dari cuplikan di atas, dapat dipahami praktik tranformatif yang dilakukan oleh mahasiswa dalam hal memahami karya sastra novel kemudian memahami nilai moral dalam novel. Pemahaman ini mendorong mahasiswa untuk merancang perubahan tingkah laku untuk penanamn nilai karakter yang baik.

\section{SIMPULAN}

Kesimpulan dalam penelitian sebagai berikut. Pertama, aspek-aspek multiliterasi pada perkuliahan pendidikan bahasa dan sastra Indonesia tercermin dalam kompetensi multiliterasi. Pada mata kuliah Berbicara Dialektik, kompetensi multiliterasi yang cenderung dikembangkan adalah kompetensi linguistik, gestural, dan spasial. Pada mata kuliah Membaca Kritis Kreatif dan Sintopis, kompetensi linguistik, visual, audiovisual, dan spasial lebih banyak dikembangkan. Sementara itu, pada mata kuliah Kajian Wacana, kompetensi linguistik, spasial, dan visual lebih banyak dikembangkan.

Kedua, respon mahasiswa dan dosen terkait dengan pengembangkan kompetensi multiliterasi dalam mata kuliah Berbicara Dialektik, Membaca Kritis Kreatif dan Sintopis, serta Kajian Wacana menunjukkan hal yang positif. Dosen telah memanfaatkan sarana-sarana multiliterasi yang ada yang tercermin dari pengembangan kurikulum, pemilihan metode perkuliahan, pemanfaatan media, dan pengembangan sistem penilaian. Sementara itu, mahasiswa menilai perkuliahan yang dilakukan secara garis besar sudah memberikan manfaat dan kebermaknaan dalam kehidupan mahasiswa meskipun pengembangannya semestinya dapat dilakukan dengan lebih maksimal lagi.

\section{UCAPAN TERIMA KASIH}

Pada kesempatan ini kami ingin mengucapkan terima kasih kepada beberapa pihak yang telah membantu terselenggaranya penelitian ini. Pertama, ucapan terima kasih kami sampaikan kepada Tim I-MHERE UNY JPBSI yang telah menyeponsori penelitian dan memberikan 
dana Hibah I-MHERE tahun 2011. Kedua, terima kasih kami ucapkan kepada Rektor UNY yang telah memfasilitasi terselenggaranya penelitian. Selanjutnya, kami ucapkan terima kasih kepada tim validator instrumen, dosen dan mahasiswa yang terlibat sebagai responden, dosen JPBSI yang memberikan saran dan masukan dalam seminar bagi perbaikan penelitian, serta pihak yang tidak dapat kami sebutkan satu per satu. Harapan kami, penelitian ini dapat memberikan manfaat khususnya bagi peningkatan kualitas pembelajaran bahasa dan sastra Indonesia serta studi berbasis penelitian.

\section{DAFTAR PUSTAKA}

Barron, Nancy G. 2007. Review Buku: "Multiliteracies: Literacy: Learning and the Design of Social Futures" dalam Technical Communication Quarterly, Autumn, 16, 4.

Bazemer, J. \& Kress, G. 2008. “Writing in Multimodal Texts: A Social Semiotic Account of Designing for Learning" dalam Written Communication, 25, 2.

Borsheim, Carlin, Kelly Merritt, \& Dawn Reed. 2008. "Beyond Technology for Technology's Sake: Advancing Multiliteracies in the Twenty-First Century" dalam The Clearing House NovemberDesember. www.proquest.umi.pqd/ web

Coughlan, Samantha. 2008. "Advocating for the Arts in an Age of Multiliteracies" dalam Language Arts, 86, 2. www. proquest.umi.pqd/web

Edlesky, C. 2006. With Literacy and Justice for All: Rethinking the Social in Language and Education ( ${ }^{\text {rd }} e d$ ). Mahwah, NJ: Erlbaum.

Fairclaugh, N. 1989. Language and Power. New York: Longman.

Fairclaugh, Norman. 1992. Critical Discourse Analysis: The Critical Study of Language. USA: Longman.
Gee, J. 1992. The Social Mind: Language, Ideology, and Social Practice. New York: Begin \& Garvey.

Graham, Meadow Sherril, Sheila Benson, Lisa Storm Fink. 2010. "A Springboard Rather Than a Bridge: Diving into Multimodal Literacy" dalam English Journal (High School Edition) Urbana: November, vol 200, 153.

Hasset, Dawnene D., dan Jen Scoot Curwood. 2009. "Theories and Practice of Multimodal education: The Instructional Dynamics of Picture Book and Primary Classroom" dalam The Reading Teacher 63, 4. International Reading Association. www.proquest. umi.pqd/web

Knapp, Peter \& Megan Watkins. 2005. Genre, Text, and Grammar. Sidney, NSW: New South Wales University Press, Ltd.

Kress, G. 2003. Literacy in te New Media Era. London: Routledge.

New London Group. 1996. A Pedagogy of Multiliteracies: Designing Social Futures. Harvard Educational Review, 66.

Siegel, M. 2006. Rereading the Sign: Multimodal Tranformations in the Field of Literacy Education dalam Language Arts, 84, 1. www.proquest.umi.pqd/ web

Vasquez, V. 2003. Getting Beyond "I Like the Book": Creating Space for Critical Literacy in K-6 Classrooms. Newark, DE: International Reading Association.

Vygotsky, L. 1986. Thought and Language. Cambridge, MA: The MIT Press. York: Bergin \& Garvey.

Williams, Bronwyn T. 2008. "Tomorrow will not be like today": Literacy and Identity in a World of Multiliteracies. International Reading Association. www.proquest.umi.pqd/web 